\title{
Perspective
}

\section{Serotonin Function in Panic Disorder: Important, But Why?}

\author{
Eduard Maron*, ${ }^{*}$ and Jakov Shlik ${ }^{2}$ \\ 'Department of Psychiatry, University of Tartu, Tartu, Tartumaa, Estonia; ${ }^{2}$ Department of Psychiatry, University of Ottawa, Ottawa, \\ ON, Canada
}

\begin{abstract}
The essential role of serotonin (5-hydroxytryptamine (5-HT)) system in the neurobiology and pharmacotherapy of panic disorder (PD) continues to be a topic of intensive interdisciplinary research. Interest in the involvement of 5-HT in PD has been fuelled by clinical studies demonstrating that medications increasing the synaptic availability of $5-\mathrm{HT}$, such as selective $5-\mathrm{HT}$ re-uptake inhibitors, are effective in the treatment of PD. Rival theories of 5-HT deficiency vs excess have attempted to explain the impact of 5-HT function in PD. In the past decade, knowledge of the role of 5-HT in the neurobiology of PD has expanded dramatically due to much new research including experimental, treatment, brain-imaging, and genetic studies. The current review attempts to summarize the new data and their implications. The challenge and treatment studies generally confirm the specific inhibitory influence of 5-HT on panicogenesis. The brainimaging studies in PD patients demonstrate functional and clinically relevant alterations in various elements of 5-HT system affecting the neurocircuitry of panic. The findings of genetic association studies suggest that certain 5-HT-related genes may contribute to the susceptibility to PD; however, these data are rather limited and inconsistent. It appears that, even if not the primary etiological factor in PD, the 5-HT function conveys important vulnerability, as well as adaptive factors. A better understanding of these processes may be critical in achieving progress in the treatment of patients suffering from PD.

Neuropsychopharmacology (2006) 3 I, I - I I. doi: I0.1038/sj.npp. I300880; published online 3I August 2005
\end{abstract}

Keywords: panic disorder; serotonin; brain imaging; genetic polymorphism

\section{INTRODUCTION}

Panic disorder (PD) is a serious and prevalent psychiatric disease, the neurochemical and neurobiological origins of which are believed to be related to serotonin (5-hydroxytryptamine (5-HT)) function. Two opposing hypotheses have been put forth to explain panic phenomena by 5 -HTergic dysfunction: 5-HT excess or overactivity (Iversen, 1984; Kahn et al, 1988a, b) and 5-HT deficit or underactivity (Deakin and Graeff, 1991; Bell and Nutt, 1998). The 5-HT excess theory suggests that patients with PD either have an increased level of 5-HT release or a hypersensitivity in postsynaptic 5-HT receptors. The 5-HT deficit theory proposes that, in particular brain regions, such as the dorsal periaqueductal gray (PAG), 5-HT has a restraining effect on panic behavior and a 5-HT deficit may facilitate panic. Deakin and Graeff (1991) also proposed that the 5-HT system plays a dual role in the modulation of different forms of pathological anxiety by inhibiting panic responses, but contributing to anticipatory or generalized anxiety. In the past decade, the specific involvement of 5-HT in the

*Correspondence: Dr E Maron, Department of Psychiatry, University of Tartu, Raja 31, Tartu, Tartumaa 50417, Estonia, Tel: + 3727318 812, Fax: +372 7318 80I, E-mail: eduard.maron@kliinikum.ee

Received I5 March 2005; revised 9 June 2005; accepted 20 July 2005 Online publication: 25 July 2005 at http://www.acnp.org/citations/ Npp072505050 83/default.pdf pathogenesis and neurobiology of $\mathrm{PD}$ has been extensively tested in a broad scope of investigations including clinical and experimental studies, brain imaging, and genetics. The aim of the current paper is to review the results and implications of these studies in order to update current knowledge on the functional role of 5-HT system in PD.

\section{TREATMENT STUDIES}

Clinical studies consistently show the efficacy of medications which increase the synaptic availability of 5-HT, such as monoamine oxidase (MAO) inhibitors and selective 5-HT re-uptake inhibitors (SSRIs), in the treatment of PD (Tyrer and Shawcross, 1988; Kent et al, 1998; Nutt, 1998). Extensive experience with SSRIs in the treatment of PD underscores the necessity of increased synaptic availability of 5-HT for achieving remission. However, the molecular correlates of SSRI treatment effects remain obscure. Notably, SSRIs may exacerbate anxiety during the initial phase of treatment, indicating the possible oversensitivity of 5-HT postsynaptic receptors (Coplan et al, 1992).

Despite the initial worsening of anxiety with SSRI treatment, numerous observations of the antipanic effect of 5-HT provide support for the 5-HT-deficit hypothesis. It has been reported that patients with PD gained relief from the administration of 5-HT precursor, 5-hydroxytryptophan (5-HTP) (den Boer and Westenberg, 1990a). In addition, 
5-HTP had beneficial effects on panic attacks in patients with anxiety disorders (Kahn and Westenberg, 1985; Kahn et al, 1987). A favorable effect of 5-HT releaser/reuptake inhibitor D-fenfluramine (dFEN) in the treatment of PD also has been reported (Solyom, 1994). Buspirone, a partial 5-HT1A agonist with a primary presynaptic effect on 5HT1A autoreceptors, inhibits firing of 5-HT cells. Buspirone is effective in the treatment of generalized anxiety disorder (GAD), but not in PD (Bell and Nutt, 1998). Another selective 5-HT1A receptor agonist, ipsapirone, may also be effective in the treatment of GAD (Cutler et al, 1994); however, acute administration of ipsapirone is panicogenic (Broocks et al, 2003). Apart from 5-HT-ergic pathways, the panicogenic effect of ipsapirone may be mediated by a noradrenergic activation via the locus coeruleus (Sanghera et al, 1990). Patients with PD did not respond to treatment with 5-HT2A receptor antagonists, such as ritanserin, which actually exacerbated some symptoms, although these drugs may be beneficial in the treatment of GAD (Bressa et al, 1987; den Boer and Westenberg, 1990b). Altogether, these clinical data are in favor of the 5-HT-deficit hypothesis in PD. Moreover, the fact that 5-HT antagonists have no clinically relevant antipanic effects argues against the 5-HT overactivity theory of PD (den Boer and Westenberg, 1990b; Marek et al, 1992).

\section{CHALLENGE STUDIES}

The 5-HT-ergic mechanisms of anxiety and panic have been studied experimentally using dFEN and $m$-chlorophenylpiperazine (m-CPP) as challenge agents. The experience of $\mathrm{dFEN}$-induced anxiety is quite heterogeneous, including 'waves' of anxiety persisting for hours, appearing to resemble generalized anxiety rather than panic attacks (Hollander et al, 1990; Mortimore and Anderson, 2000). An oral dose of up to $60 \mathrm{mg}$ dFEN evoked anxiety symptoms, including panic, and elevated cortisol and prolactin responses in PD patients $v s$ healthy subjects (Targum and Marshall, 1989).

$\mathrm{m}-\mathrm{CPP}$ is a mixed agonist of 5-HT1/5-HT2 and antagonist of 5-HT2, 5-HT3, and $\alpha$-adrenergic receptors (Barnes and Sharp, 1999). This agent acutely induces panic and/or anxiety symptoms in PD patients (Kahn et al, 1988b; Klein et al, 1991). Patients with PD had an augmented cortisol release induced by oral administration of $\mathrm{m}-\mathrm{CPP}$ $(0.25 \mathrm{mg} / \mathrm{kg})$ as compared to controls or depressive patients (Kahn et al, 1988a). However, in another study, Kahn et al (1991) found that oral administration of m-CPP $(0.25 \mathrm{mg} / \mathrm{kg})$ induced an augmented release of adrenocorticotropic hormone and prolactin in female but not male patients with PD. Subsequent studies with a lower intravenous $\mathrm{m}$-CPP dose yielded more panic effects in patients with PD and a blunted prolactin response in female patients (Germine et al, 1994). These results suggest a genderrelated hypersensitivity of 5-HT receptors in PD. Additionally, there is evidence of behavioral hypersensitivity to the oral administration of $\mathrm{m}$-CPP and ipsapirone, suggestive of opposite changes in the responsiveness of 5-HT2C and 5-HT1A receptors in PD patients (Broocks et al, 2000).

Nevertheless, not all studies confirm the findings of hypersensitive postsynaptic 5-HT receptors. Charney et al
(1987) have demonstrated that behavioral ratings of anxiety and panic, as well as hormonal changes in response to $\mathrm{m}$-CPP challenge $(0.1 \mathrm{mg} / \mathrm{kg})$, did not differ between PD and controls. Although this may have been related to the use of high-dose $\mathrm{m}$-CPP, even the lower dose of $\mathrm{m}$-CPP $(0.06 \mathrm{mg} / \mathrm{kg})$ did not reveal any biochemical or behavioral differences between PD and healthy subjects (Wetzler et al, 1996). Apparently, both dFEN and m-CPP do not meet the postulated criteria for an ideal laboratory panicogen as their test-retest reliability is unknown and they lack specificity in PD (Swain et al, 2003). These agents may also cause panic symptoms indirectly via their anxiogenic effects. Grove et al (1997) have indicated that the ventral amygdalofugal pathway projects to the PAG, implicating 5-HTinduced amygdaloid hyperactivity in the mediation of anticipatory anxiety as well as the induction of the priming process of the PAG, lowering its threshold for the occurrence of panic.

Taken together, the duality of 5-HT system in the mediation of different types of anxiety (Deakin and Graeff, 1991), as well as the complex reciprocal relationship within the panic circuitry (Grove et al, 1997), may explain the difficulty in uncoupling the anxiogenic and panicogenic effects of 5-HT-ergic agents.

Use of panic challenge combined with a manipulation of the 5-HT system may be especially informative for clarifying the role of 5-HT in PD. Two direct 5-HT-ergic interventions appear to be particularly relevant in this regard. First is the acute tryptophan depletion (TD) causing substantial decrease in the brain 5-HT levels (Bell et al, 2001; Young et al, 1985). Although TD alone is not anxio- or panicogenic in unmedicated PD patients (Goddard et al, 1994), it did increase respiration and subjective breathlessness in PD patients as compared to healthy subjects (Kent et al, 1996). The opposite approach to using TD is to increase the brain concentration of $5-\mathrm{HT}$ by using precursors of 5-HT synthesis (den Boer and Westenberg, 1990a; van Vliet et al, 1996). Studies with 5-HT precursors alone did not demonstrate any differences in the reactivity of PD patients and healthy subjects (Charney and Heninger, 1986; den Boer and Westenberg, 1990a). These 5-HT-ergic interventions may be combined with various panic challenges, including use of 5-HT-ergic agents as well as the benzodiazepine receptor antagonist flumazenil, carbon dioxide $\left(\mathrm{CO}_{2}\right)$ or cholecystokinin-tetrapeptide (CCK-4), a CCK brain subtype receptor agonist.

Kent et al (1996) have demonstrated that TD worsened the respiratory response to $5 \% \mathrm{CO}_{2}$ challenge in $\mathrm{PD}$ patients as compared to healthy subjects, but no significant betweengroup differences were observed on measures of panic or anxiety. A later study of Klaassen et al (1998) in healthy subjects has shown that TD significantly increased 35\% $\mathrm{CO}_{2}$-induced somatic, but not cognitive, panic symptoms in male subjects with a similar panic rate in TD and placebo groups. Koszycki et al (1996) have found that TD did not influence the panicogenic effect of CCK-4 in healthy males, although it did augment CCK-4-mediated neuroendocrine activation. Further studies have proven that TD increases the sensitivity to $\mathrm{CO}_{2}$ challenge in patients with $\mathrm{PD}$. Specifically, Miller et al (2000) found that TD caused a greater panic and anxiogenic response and a higher rate of panic attacks after $5 \% \mathrm{CO}_{2}$ inhalation in PD patients, but 
not in healthy subjects. Another study in patients by Schruers et al (2000) demonstrated a significant increase in anxiety and panic symptoms induced by $35 \% \quad \mathrm{CO}_{2}$ inhalation in the TD group, compared to the placebo condition. Conversely, Schruers et al (2002) found that increasing 5 -HT by the acute administration of $200 \mathrm{mg}$ 5 -HTP restrained panic responses to $35 \% \mathrm{CO}_{2}$ challenge in patients with $\mathrm{PD}$, but not in healthy subjects. Our recent study in healthy volunteers has demonstrated that $200 \mathrm{mg}$ of 5-HTP significantly lowered the panic rate and intensity of cognitive panic symptoms in females and intensity of somatic symptoms in males (Maron et al, 2004c).

Although it is quite clear that acute pretreatment with 5-HTP increases the net amount of released 5-HT and its synaptic availability (Dreshfield-Ahmad et al, 2000; Fickbohm and Katz, 2000), the antipanic mechanism of 5-HTP requires further study. The increase in plasma cortisol and prolactin following 5-HTP administration in man is modulated by at least three different postsynaptic receptors, the 5-HT1A, 5-HT2A, 5-HT2C, and 5-HT3 receptors (Meltzer and Maes, 1994; Meltzer et al, 1997). Pretreatment with pindolol, a 5-HT1A partial antagonist, significantly inhibited the prolactin, but not the cortisol response to 5-HTP (Meltzer and Maes, 1994), whereas ritanserin, a 5-HT2A/5-HT2C antagonist, did not block the prolactin response to tryptophan (Deakin, 1996) and even increased it in another study (Charig et al, 1986). However, it is not known whether neuroendocrine and antipanic effects of 5-HTP are mediated via the same 5-HT receptors. Therefore, further experimental studies with selective 5-HTergic antagonists are needed to clarify the antipanic action of 5-HTP and its clinical relevance. Studies with 5-HT-ergic agents have shown that administration of dFEN tended to inhibit $7 \% \mathrm{CO}_{2}$ panic challenge (Mortimore and Anderson, 2000), while mixed $5-\mathrm{HT} 2 \mathrm{~A} / 2 \mathrm{C}$ and $5-\mathrm{HT} 1 \mathrm{~B} / \mathrm{D}$ receptors antagonist metergoline increased the anxiogenic response to $35 \% \mathrm{CO}_{2}$ inhalation in healthy subjects (Ben-Zion et al, 1999). An antagonist of 5-HT3 receptor ondansetron attenuated CCK-4-induced panic attacks acutely, but not after chronic treatment in healthy volunteers (Depot et al, 1999), and did not prevent the panicogenic effects of CCK-4 analog pentagastrin in patients with PD (McCann et al, 1997).

\section{EFFECTS OF TREATMENT ON PANIC CHALLENGE}

The investigation of 5-HT-ergic treatment effects on the sensitivity to panicogenic agents is another pertinent way to clarify the protective role of 5-HT in PD. Studies so far have shown that treatment with SSRIs significantly decreased the sensitivity of patients with PD to the panicogenic effects of CCK-4, flumazenil, and $\mathrm{CO}_{2}$ (Bell et al, 2002; Bertani et al, 1997; Perna et al, 1997; Shlik et al, 1997; van Megen et al, 1997). These results support the view that 5-HT-ergic enhancement by SSRIs leads to antipanic effects. Recently, Schruers and Griez (2004) reported that 6-week treatment with tianeptine had an antipanic effect on the $35 \% \mathrm{CO}_{2}$ panic challenge in $\mathrm{PD}$ patients similar to the effect seen with the SSRI paroxetine. These findings are of interest considering that, contrary to SSRIs, tianeptine is believed to increase the 5-HT reuptake. A recent study by the Bristol group found that TD reversed the antipanic effect of chronic treatment with the SSRI paroxetine in PD patients, manifested as an increase in panicogenic response to a flumazenil challenge (Bell et al, 2002). This supports the assumption that SSRIs exert their therapeutic effects in PD by increasing the synaptic availability of 5-HT (Nutt et al, 1999). In sum, most of the above-mentioned studies demonstrate that a decrease in 5-HT synaptic availability increases susceptibility to panic and, conversely, an increase in 5-HT neurotransmission has antipanic effects. However, it is still not known whether the possible 5-HT deficit is a primary factor or whether 5-HT has protective influence on other excitatory neurotransmission systems that may be responsible for triggering panic attacks.

\section{BRAIN IMAGING OF 5-HT SYSTEM IN PD}

The brain-imaging research has provided more evidence of neurobiological substrates in PD (Talbot, 2004). Recently, we performed a single-photon emission computed tomography study of the functional activity of 5-HT transporter (5-HTT) in PD using radioligand [(123)I]nor-beta-CIT (Maron et al, 2004a). The results of this study showed that the patients with current PD had significantly lower 5-HTT binding in the midbrain raphe, in the temporal lobes, and in the thalamus than the healthy controls. The patients with PD in remission had normal 5-HTT-binding properties in the midbrain and in the temporal regions, but still a significantly lower thalamic 5-HTT binding. Furthermore, a recent positron emission tomography (PET) study revealed a marked reduction of 5-HT1A receptor binding in the anterior and posterior cingulate cortices, and in the midbrain raphe in patients with $\mathrm{PD}$ in comparison to healthy controls without any between-group differences in the anterior insula, the mesiotemporal cortex, and the anterior temporal cortex (Neumeister et al, 2004). Another PET study has demonstrated that untreated PD patients showed reduced binding to 5 -HT1A receptors in the raphe region as well as in the amygdala, and the orbitofrontal and temporal cortices (Nash et al, 2004). PD patients who fully recovered after treatment with the SSRI paroxetine in this study showed normalized density of postsynaptic receptors, but there remained a reduction in the density of 5-HT1A receptors in the raphe and in the hippocampus, suggesting the trait nature of these alterations. Notably, the pre- and postsynaptic 5-HT1A receptors differ in many aspects, including neurochemical and neuroendocrine responses. Presynaptic 5-HT1A receptors play a crucial role in the regulation of 5-HT release at the level of the raphe nuclei, while postsynaptic 5 -HT1A receptors modulate the release of norepinephrine and stress hormones. However, behavioral responses mediated by these two types of receptors are not clearly distinguishable (Barnes and Sharp, 1999). On the whole, brain-imaging studies point to a reduced density of 5-HTT as well as 5-HT1A receptors in PD. It is conceivable that these changes reflect a deficit in 5-HT neurotransmission or a compensatory process in the 5-HT system that attempts to increase the availability of synaptic 5-HT. The downregulation of postsynaptic 5-HT1A receptors, however, is not likely to reflect an adaptive response to abnormal 5-HT release because reducing 5-HT transmission 
by lesioning the raphe or administering 5-HT synthesis inhibitors does not alter 5-HT1A receptor binding in the cerebral cortex or the hippocampus (Frazer and Hensler, 1990; Hensler et al, 1991; Pranzatelli et al, 1994; Verge et al, 1986). Also, an increased 5-HT transmission after treatment with an SSRI or MAOI does not consistently alter 5-HT1A receptor density or mRNA concentrations in the cortex, hippocampus, or amygdala (Carli et al, 1996; Hensler et al, 1991; Spurlock et al, 1994; Welner et al, 1989). Furthermore, it is not clear whether the reduction in 5-HTT and 5-HT1A receptors has any region-specific influence on the 5-HT neurotransmission in PD. The critical question which remains to be answered is whether there is a deficit in 5-HT synthesis and/or in 5-HT neurotransmission in patients with PD. This could be clarified further in brain-imaging studies measuring the 5-HT synthesis rate in different stages of PD.

\section{5-HT SYSTEM AND PANIC CIRCUITRY}

The imaging data also serve to elucidate the place of the 5 -HT system in the neuronal circuitry of PD. According to the neuroanatomical hypothesis of Gorman et al (2000), panic attacks originate from a dysfunction in the brain fear network that integrates various structures of the brainstem, the amygdala, the medial hypothalamus, and cortical regions. The 5-HT system is well positioned to influence these areas with its neuronal cell bodies in the brainstem raphe nuclei and widespread axonal projections to the forebrain regions (Jacobs and Azmitia, 1992; Lucki, 1998). Among the limbic forebrain areas, the septum and the dorsal hippocampus are innervated mainly by the median raphe nucleus (MRN), whereas the amygdala and the ventral hippocampus are innervated almost exclusively by the dorsal raphe nucleus (DRN). Also, the thalamus and the PAG matter of the midbrain receive 5-HT input via the DRN-periventricular tract. In the neocortex, the majority of the 5-HT projections come from the DRN through the dorsal raphe-cortical tract, which projects diffusely to the parietal and temporal cortices. The cortical projections of the MRN also travel via the medial forebrain bundle and reach the frontal, cingulate, and entorhinal cortices (Graeff, 1997). Deakin and Graeff (1991) suggested that direct 5-HT projections from DRN play an important role in restraining panic via their inhibitory influence on the dorsal PAG. The demonstrated decreases in the midbrain 5-HTT and 5-HT1A receptor binding could reflect a compensatory process attempting to increase 5-HT neurotransmission, particularly in dorsal PAG, in order to inhibit overactivity or a spontaneous neuronal discharge in this region. The presence of a persistent reduction in the raphe 5-HT1A receptors in remitted or panic-free $\mathrm{PD}$ patients could result in an increase in the firing rate of 5-HT neurons, which in turn could increase or facilitate the release and neurotransmission of 5-HT to terminal projections including PAG (Figure 1). In addition, the observed normalization of 5-HTT and 5-HT1A binding in the temporal lobes, which are also innervated by DRN, could be directly or indirectly related to the increased 5-HT neurotransmission. As discussed above, the normal 5-HT1A binding in the amygdala and frontal cortices in remitted PD patients has
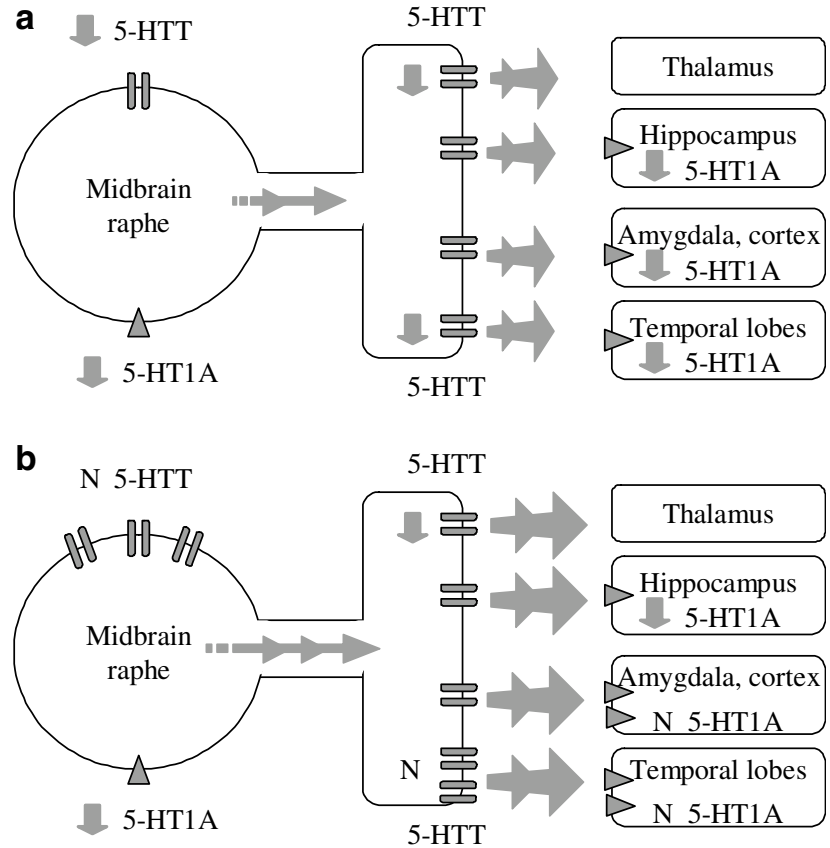

Figure I This figure represents a hypothetical framework for the regulation of 5-HT system in $\mathrm{PD}$. (a) Function of 5-HT system in current PD patients in symptomatic stage. This is characterized by reductions in the density of 5-HTT and 5-HTIA receptors in the midbrain raphe, as well as in the terminal projections to other brain structures. Based on the evidence that the low synaptic 5-HT availability augments and increased 5-HT availability inhibits panic attacks, the reduced density of both, 5-HTT and 5-HTIA, receptors may reflect a compensatory process in the 5-HT system, attempting to increase 5-HT neurotransmission. (b) Function of 5-HT system in remitted panic-free PD patients. In this stage, 5-HTT density is normalized in the midbrain raphe and in the temporal lobes, but remains decreased in the thalamus. On the other hand, the density of 5 HTIA receptors is normal in other brain regions, including the amygdala, orbitofrontal, and temporal cortices, but significantly reduced in the hippocampus and in the midbrain raphe. The normalization in 5-HT function could stem from an increased 5-HT neurotransmission that in turn restrains the panicogenesis. Persistent reduction in the midbrain raphe 5-HTIA receptors may increase the firing rate of $5-\mathrm{HT}$ neurons and facilitates 5-HT release. Unaffected reductions in thalamic 5-HTT and hippocampal 5-HTIA receptor density may reflect trait alterations in the 5-HT system that, probably, are related to increased interoceptive sensitivity or decreased tolerance to anxious and stressor stimuli, respectively.

a disputable relationship to alterations in 5-HT neurotransmission, but still may be related to the symptomatic improvement. According to the Deakin-Graeff theory, 5-HT projections from DRN facilitate active escape or avoidance behaviors in response to potential threat or aversive stimuli at the level of the frontal cortex and the amygdala, and may be related to anticipatory or generalized anxiety. On the other hand, Grove et al (1997) proposed that 5-HT-induced enhancement of the MRN function could suppress cortical and amygdalo-hippocampal activation. It has also been suggested that failure of the MRN to contain chronic stressinduced overstimulation of the central nucleus of the amygdala/PAG axis in PD may cause normal anxiogenic stimuli to become panicogenic (Grove et al, 1997). However, the dual role of the rostral 5-HT systems in panicogenesis and current technical limitations in the distinction between MRN and DRN complicate the understanding of the role of postsynaptic 5-HT1A receptors in panic neurocircuitry. The 
animal studies demonstrating abolition of anxiety in 5-HT1A receptor knockout mice by rescue of postsynaptic receptor expression (Gross et al, 2002) and clinical evidence indicate that normalization of 5-HT1A binding in the amygdala and frontal cortices has an anxiolytic effect that could contribute to relief from panic symptoms. In addition, according to the Deakin-Graeff hypothesis, the MRN-hippocampal 5-HT pathway promotes resistance to chronic, unavoidable stress via 5 -HT1A receptors, whereas failure of this mechanism may lead to depression. Moreover, the neuronal network between the hippocampus, cortical structures, and amygdala may be involved in cognitive attributions of fear stimuli and the enhancement of memory function facilitating adaptive responses (Goddard and Charney, 1997). It would therefore be tempting to speculate that a persistent reduction in the binding of hippocampal 5-HT1A receptors in PD patients may reflect a decreased tolerance for or a maladaptive responsiveness to stressors. Previously, a reduction in 5-HT1A receptorbinding potential in various brain regions, including the hippocampus, was also demonstrated in patients with depression (Drevets et al, 1999). The other pertinent finding was the persistent decrease of thalamic 5-HTT binding in remitted patients with $\mathrm{PD}$. Considering that the thalamus is a sensory relay station channeling environmental stimuli to the sensory cortices and the amygdala (Phillips and LeDoux, 1992), the reduced thalamic binding of 5-HTT may reflect an increased interoceptive sensitivity and anticipatory anxiety, both common in $\mathrm{PD}$ even during the remission stage. Taken together, the brain-imaging studies of the 5-HT system in PD help map the involvement of 5-HT-ergic pathways in panic circuitry. However, further delineation of the region-specific role of 5-HT-ergic projections from the MRN and DRN is needed for more precise characterization of the impact of 5-HT on PD pathogenesis.

\section{5-HT GENES AND PD}

There are increasing efforts to determine PD vulnerability genes in the 5-HT system. Association studies in PD have been focused on known targets of antidepressants and challenge agents, or based on findings in other psychiatric disorders. Overall, the studies of gene polymorphisms in the 5-HT system in PD have produced results that are inconsistent, negative, or not clearly replicable (Table 1); however, there is potential for advances with the use of novel high-throughput genotyping and haplotype analyses.

\section{5-HTT Gene}

Results of previous case-control association studies in different ethnic populations argue against a major role of a functional polymorphism in the promoter region of 5-HTT consisting of a 44 base pair insertion/deletion (5-HTTLPR) in PD (Deckert et al, 1997; Ishiguro et al, 1997; Matsushita et al, 1997). As well, neither linkage nor association between 5-HTTLPR and PD was observed in a family-based study; however, a more frequent occurrence of 5-HTTLPR LL genotype was detected in female PD probands (Hamilton et al, 1999). Nevertheless, our group recently found significant differences in the distribution of 5-HTTLPR genotypes and allele frequencies between PD patients and controls, with the LL genotype and L allele variant being more frequent in patients (Maron et al, 2005a). Pertinently, another study found that healthy females with the LL genotype were more sensitive to CCK-4-induced panic attacks than those who are carriers of S allele (Maron et al, 2004b). Also Schmidt et al (2000) reported that subjects homozygous for the long variant were at greater risk for behavioral hyper-reactivity to $35 \% \mathrm{CO}_{2}$ challenge than those with short-allele genotypes. On the contrary, in patients with $\mathrm{PD}, \mathrm{CO}_{2}$ reactivity was not influenced by 5-HTTLPR genetic variants (Perna et al, 2004). On the other hand, the long-allele variant of 5-HTTLPR has been associated with a better response to SSRI treatment in females with PD (Perna et al, 2005). In healthy subjects, the short allele of 5-HTTLPR has been associated with anxiety-related personality traits (Lesch et al, 1996) and with a greater activation of the amygdala in response to fearful face stimuli (Hariri et al, 2002). This speaks to a link between the lower activity of 5HTT and anxiety proneness that opposes the possible antipanic direction of this genotype. Perhaps, this discrepancy may be explained by different roles of the 5-HT system in the neuronal circuits of anxiety and panic attacks, as proposed by Deakin and Graeff (1991). Based on these findings, the role of 5-HTTLPR variants in the predisposition to PD warrants further investigation. Notably, a recently detected genetic variation (16A allele) in the long allele of 5-HTTLPR has been linked to a lower expression of 5-HTT (Gingrich et al, 2004). This finding may shed a different light on the results from preceding association studies with 5-HTT polymorphisms, and should be accounted for in further research. Finally, a number of other known 5-HTT polymorphisms were not found to be associated with PD clinical phenotypes (Table 1).

\section{MAO-A Gene}

The transcriptionally more active longer alleles and genotypes of a functional polymorphism of the MAO-A gene, uVNTR, demonstrated a significant association with PD in female but not male patients (Deckert et al, 1999). We found a similar gender-dependent association with longer allele genotypes in female PD patients with agoraphobia (Maron et al, 2005a). Recently, Samochowiec et al (2004) observed a significant association with longer alleles in females with panic attack phenotypes. Again, this association was absent in males. All these studies suggest an impact of MAO-A promoter region polymorphism on vulnerability to PD; however, a family-based study did not support these findings (Hamilton et al, 2000). Another polymorphism of the MAO-A, Fnu4H1, was not associated with PD (Tadic et al, 2003).

\section{TPH Gene}

No associations with PD were found for various variants of TPH1 gene (Fehr et al, 2001; Han et al, 1999; Maron et al, 2005b). However, the newly identified isoform 2 of TPH gene (TPH2), rather than TPH1, is preferentially expressed in the neuronal tissue and has functional polymorphisms involved in the regulation of brain 5-HT synthesis (Zhang et al, 2004). This may explain the negative findings with 
Table I Association Studies of 5-HT-Related Genes in PD

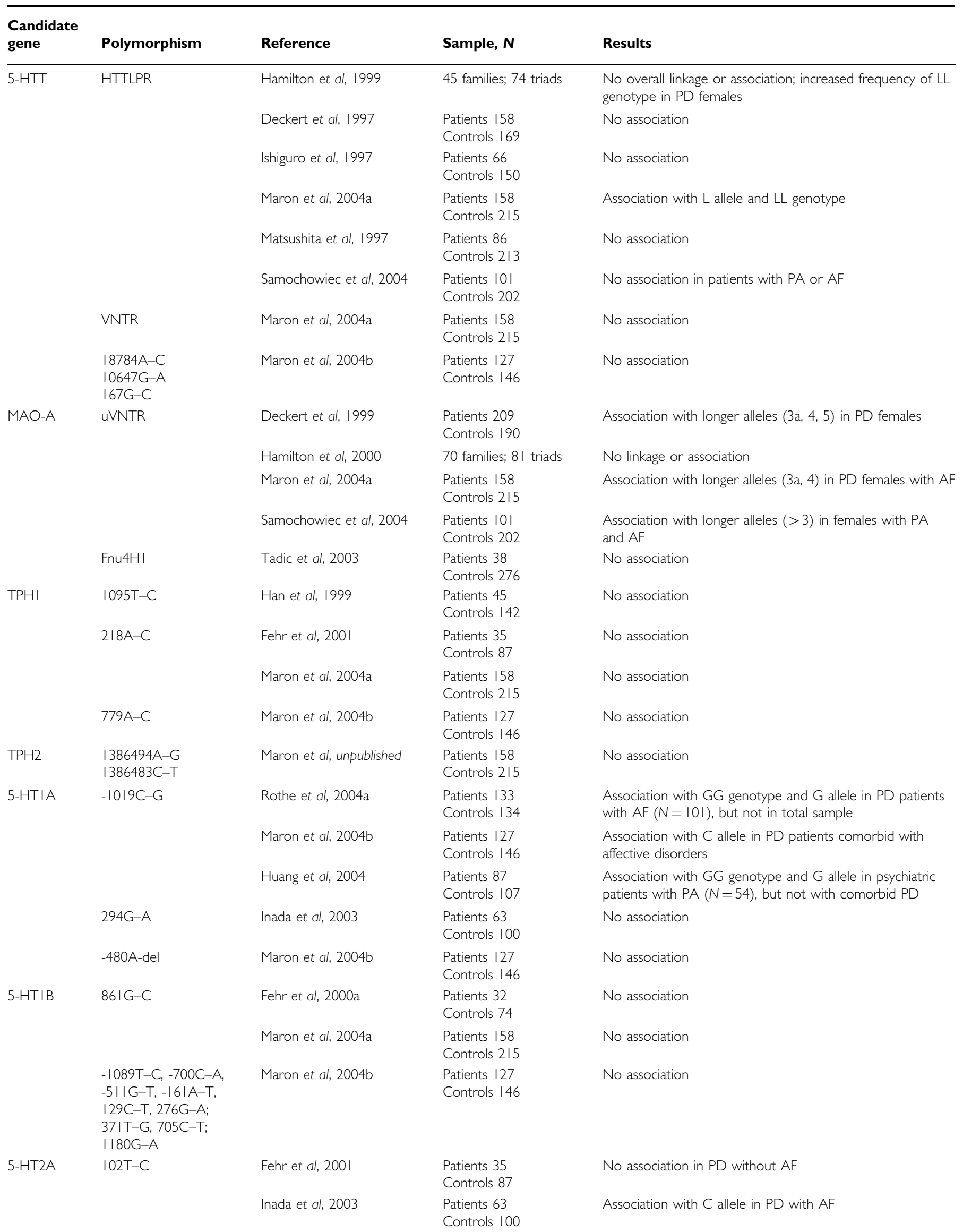


Table I Continued

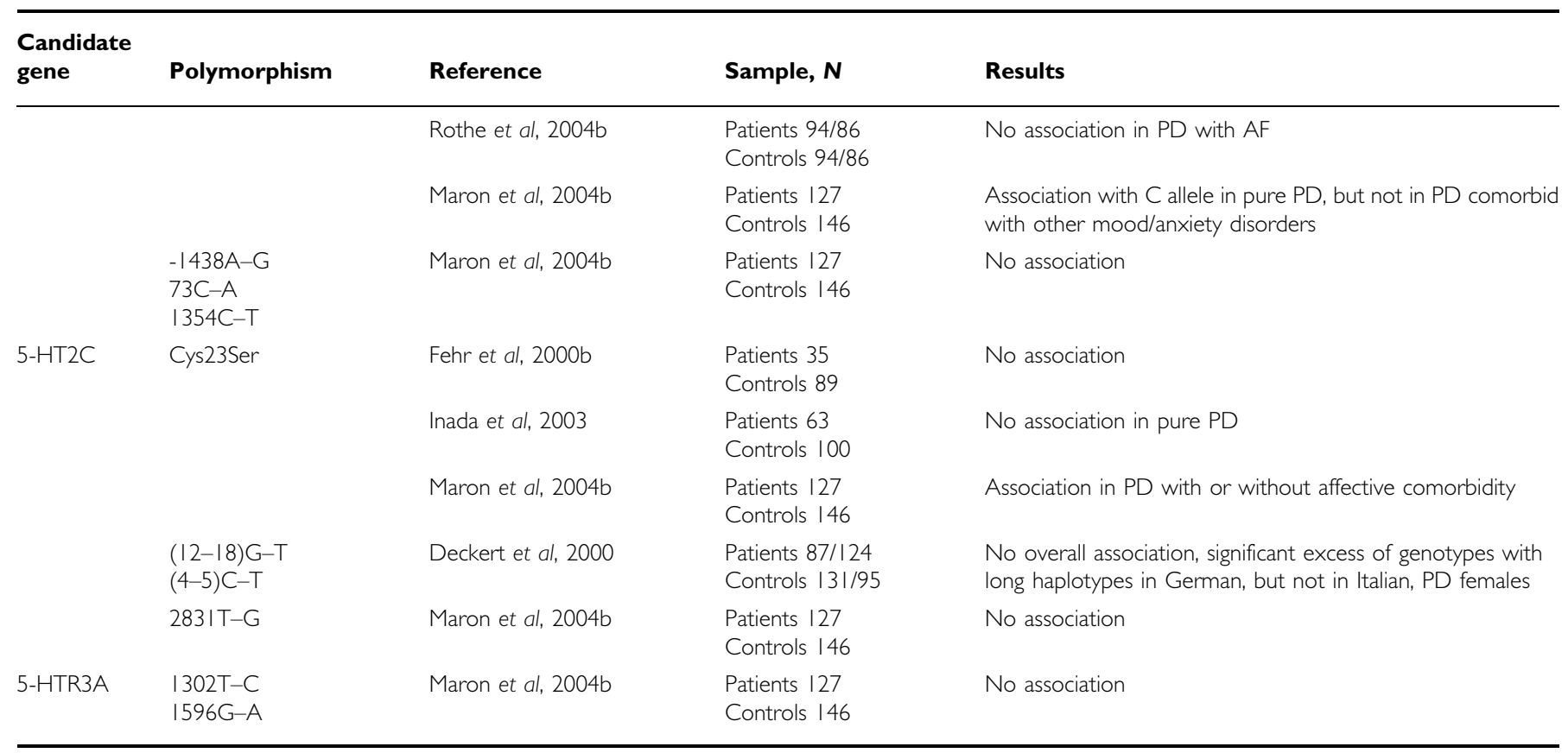

TPH1 gene polymorphisms in PD, and suggests the importance of including TPH2 polymorphisms in the genetic association studies in PD. So far, our preliminary results indicated a lack of association between 1386494A-G or $1386483 \mathrm{C}-\mathrm{T}$ polymorphisms of TPH2 and PD (unpublished data).

\section{5-HT Receptor Genes}

A common $-1018 \mathrm{C}-\mathrm{G}(-1019 \mathrm{C}-\mathrm{G})$ functional polymorphism in the promoter region of the human 5-HT1A receptor gene has been recently described (Lemonde et al, 2003; Wu and Comings, 1999). Lemonde et al (2003) postulated that the $-1019 \mathrm{G}$ allele results in impaired repression of the 5-HT1A receptor gene, leading to elevated levels of 5-HT1A autoreceptor and inhibition of basal raphe neuronal activity. However, the relationship between this polymorphism and 5-HT1A receptor binding in the prefrontal cortex was not confirmed (Huang et al, 2004), suggesting that 5-HT1A receptor responsiveness in the adult brain is not robustly influenced by variants of this gene (Lesch and Gutknecht, 2004). A recent study by Rothe et al (2004a) showed an association between the $-1019 \mathrm{C}-\mathrm{G}$ polymorphism and PD with agoraphobia, but no association among the total sample of PD patients. Our study demonstrated a suggestive association of this SNP with PD phenotype (Maron et al, 2005b). Of note, Rothe et al (2004a) showed a significant association with the $\mathrm{G}$ allele, whereas our results revealed an association with the $\mathrm{C}$ allele. Thus, PD's association with 5-HT1A -1019C-G needs further clarification. Association of 5-HT1A -1019C-G with the presence of panic attacks was also observed in other psychiatric disorders, including major depression, bipolar disorder, and schizophrenia; however, this association was not present in patients with comorbid diagnosis of $\mathrm{PD}$, probably due to the lower diagnostic reliability in the last group (Huang et al, 2004). Other data showed lack of association between PD phenotypes and several other 5-HTR1A receptor polymorphisms (Inada et al, 2003; Maron et al, 2005b).

5-HT1B receptor gene $861 \mathrm{G}-\mathrm{C}$ polymorphism did not demonstrate any significant association in patients with $\mathrm{PD}$ (Fehr et al, 2000a; Maron et al, 2005a). Furthermore, no associations were found between PD phenotypes and a large number of SNPs in this gene, excluding the major role of the 5-HT1B receptor gene in PD (Maron et al, 2005b).

Recently, Inada et al (2003) detected a significant association with 5-HT2A receptor silent $102 \mathrm{~T}-\mathrm{C}$ polymorphism in PD patients with pure phenotype and in particular with agoraphobia. Our study also showed a significant association with the 5 -HT2A receptor $102 \mathrm{~T}-\mathrm{C}$ polymorphism in pure, but not in comorbid, PD (Maron et al, 2005b). Both studies showed that the 102C allele was more frequent among patients, suggesting a significant role for this allele in the predisposition to $\mathrm{PD}$. In contrast, the role of the 5-HT2A 102T-C polymorphism in PD was not supported in a study with a combined Canadian and German sample of patients (Rothe et al, 2004b), whereas neither transmission disequilibrium between $102 \mathrm{~T}-\mathrm{C}$ alleles and PD nor allelic or genotypic differences in the casecontrol analysis were detected. Also, previously Fehr et al (2001) did not find significant association with the 102T-C polymorphism of the 5-HT2A receptor gene among their small sample of German PD patients without agoraphobia. The ethnic heterogeneity may account for these inconsistent results, but different $\mathrm{PD}$ phenotypes may also explain diverse findings. The study of Rothe et al (2004b) allowed comorbidity with other anxiety and mood disorders; however, the comorbidity with other psychiatric disorders was not described in a sample from Fehr et al (2001). 
Conceivably, the distinct association between the 5-HT2A receptor $102 \mathrm{~T}-\mathrm{C}$ polymorphism and pure $\mathrm{PD}$ in Estonian and Japanese samples may point to a specific influence of this genetic variant on predisposition to pure PD that may lose its strength in comorbid phenotypes of PD. There is also an observation that the $\mathrm{C}$ allele has a lower expression than the $\mathrm{T}$ allele, indicating a functional role for the $102 \mathrm{~T}-\mathrm{C}$ polymorphism (Polesskaya and Sokolov, 2002). The association with the lower expressive activity allele of the 5-HT2A gene, as well as the failure of therapeutic effects or even symptomatic exacerbation in the case of 5-HT2A antagonists in patients with $\mathrm{PD}$, point to the possible beneficial effects of 5-HT2A agonism in the treatment of PD. Further to this gene, we did not found associations between PD phenotypes and several other known polymorphisms (Maron et al, 2005b).

The results of previous studies argued against a major role for the 5-HT2C receptor Cys23Ser polymorphism in PD (Fehr et al, 2000b; Inada et al, 2003). However, in our study, this polymorphism was significantly associated with PD in the total sample of patients with or without affective comorbidity (Maron et al, 2005b). Previously, a possible role for the Cys23Ser polymorphism was suggested in major depression and bipolar disorder (Lerer et al, 2001). Thus, this polymorphism may have nonspecific links to the comorbid phenotypes of $\mathrm{PD}$, but its actual impact on the predisposition to PD remains unclear. Two novel adjacent dinucleotide polymorphisms in the $5-\mathrm{HT} 2 \mathrm{C}$ receptor gene promoter region, (12-18)G-T and (4-5)C-T, were not associated with PD phenotype in German or Italian samples (Deckert et al, 2000). Nevertheless, a significant excess of genotypes containing long haplotypes of these polymorphisms was observed among PD females in the German, but not in the Italian, sample. This study demonstrated that, similar to other X-chromosomal MAO-A VNTR polymorphisms, the 5-HT2C receptor gene promoter length polymorphisms may have gender-dependent effects on the genetic vulnerability to PD.

In sum, the results of genetic association studies suggest that some gene variants of the 5-HT system, such as MAO-A uVNTR, 5-HT2A 102T-C, and probably 5-HT1A -1019C-G and 5-HTTLPR, may contribute to the susceptibility to PD. However, the 5-HT-ergic genetic influence seems to be differently related to PD phenotypes and may be genderdependent. Furthermore, the results of several studies (Inada et al, 2003; Rothe et al, 2004a; Maron et al, 2005a) support the notion of Noyes et al (1986) that PD with agoraphobia is a more severe variant of PD with a stronger genetic component.

\section{RESEARCH DIRECTIONS}

Accumulating evidence from clinical and experimental research and genetic studies points to a substantial impact of the 5-HT system on the neurobiology of PD, and supports the proposed specific inhibitory influence of 5-HT on panic (Deakin and Graeff, 1991). The molecular and receptor mechanisms of possible deficit in 5-HT synaptic availability or neurotransmission in PD need further studies. Importantly, the 5-HT system affects and is influenced by many other neurotransmitters in brain structures essential for the processing and expression of panic and anxiety (Coplan and Lydiard, 1998). Interactions between 5-HT and norepinephrine, cholecystokinin, and gamma-aminobutyric acid systems may be of particular interest for understanding the neurobiology of PD. The evidence that PD patients vary in physiological and behavioral phenotypes indicates the necessity to consider subtypes of PD in the investigation of its biogenetic basis. The endophenotype-based approach (Gottesman and Gould, 2003), including neurophysiological, biochemical, cognitive, and neuroimaging measures, could advance the research on the biological background of PD and maximize the likelihood of identifying genetic factors that influence anxiety (Smoller and Tsuang, 1998). The relationship between functional genetic variants of the 5-HT system and characteristics of 5-HTergic gene expression has become a priority on the research agenda. Gene expression profiling can be studied throughout the course of PD and thus can provide clues to molecular pathogenesis. Although gene expression in the brain may be dissimilar from the periphery, blood cells are easily available for study of gene expression and, at present, could be considered a more realistic target. In addition, new microarray technologies are likely to lead to a rapid expansion of our knowledge on the role of genetic regulation of 5-HT and other neurotransmitter systems in the expression and complexity of PD. These technologies may be particularly applicable to pharmacogenetic studies of the relationships between 5-HT-related gene polymorphisms and the outcomes of PD treatment. Evidently, PD is a biologically heterogeneous condition with important psychological components and inputs from both genetic and environmental factors. It would be an oversimplification to consider 5-HT dysfunction as the single or primary factor in PD. Perhaps the role of 5-HT system in PD is essentially adaptive rather than pathogenetic. In any case, a better understanding of 5-HT function will lead toward an elucidation of the origins of panic attacks and the improved clinical management of PD.

\section{ACKNOWLEDGEMENTS}

We acknowledge support from the Estonian Scientific Foundation grant 4614 and University of Ottawa Mental Health Research Fund (JS). The aspects of this work were presented at the 43rd Annual Meeting of the American College of Neuropsychopharmacology in San Juan, Puerto Rico, December 11-16, 2004. We thank Professor David J Nutt from the University of Bristol, UK, for helpful critical review of a draft of this manuscript and Emilie Chan, BA, for careful proofreading.

\section{REFERENCES}

Barnes NM, Sharp T (1999). A review of central 5-HT receptors and their function. Neuropharmacology 38: 1083-1152.

Bell C, Abrams J, Nutt DJ (2001). Tryptophan depletion and its implications for psychiatry. Br J Psychiatry 178: 399-405.

Bell C, Forshall S, Adrover M, Nash J, Hood S, Argyropoulos S et al (2002). Does 5-HT restrain panic? A tryptophan depletion study in panic disorder patients recovered on paroxetine. J Psychopharmacol 16: 5-14.

Bell CJ, Nutt DJ (1998). Serotonin and panic. Br J Psychiatry 172: 465-471. 
Ben-Zion IZ, Meiri G, Greenberg BD, Murphy DL, Benjamin J (1999). Enhancement of $\mathrm{CO}_{2}$-induced anxiety in healthy volunteers with the serotonin antagonist metergoline. Am J Psychiatry 156: 1635-1637.

Bertani A, Perna G, Arancio C, Caldirola D, Bellodi L (1997). Pharmacologic effect of imipramine, paroxetine, and sertraline on $35 \%$ carbon dioxide hypersensitivity in panic patients: a double-blind, random, placebo-controlled study. J Clin Psychopharmacol 17: 97-101.

Bressa GM, Marini S, Gregori S (1987). Serotonin S2 receptors blockage and generalized anxiety disorders. A double-blind study on ritanserin and lorazepam. Int J Clin Pharmacol Res 7: 111-119.

Broocks A, Bandelow B, George A, Jestrabeck C, Opitz M, Bartmann U et al (2000). Increased psychological responses and divergent neuroendocrine responses to m-CPP and ipsapirone in patients with panic disorder. Int Clin Psychopharmacol 15: $153-161$.

Broocks A, Meyer T, Opitz M, Bartmann U, Hillmer-Vogel U, George A et al (2003). 5-HT1A responsivity in patients with panic disorder before and after treatment with aerobic exercise, clomipramine or placebo. Eur Neuropsychopharmacol 13: 153-164.

Carli M, Afkhami-Dastjerdian S, Reader TA (1996). [3H]8-OHDPAT binding and serotonin content in rat cerebral cortex after acute fluoxetine, desipramine, or pargyline. J Psychiatry Neurosci 21: 114-122.

Charig EM, Anderson IM, Robinson JM, Nutt DJ, Cowen PJ (1986). L-typtophan and prolactin release: evidence for interaction between 5HT1 and 5HT2 receptors. Hum Psychopharmacol 1: 93-97.

Charney DS, Heninger GR (1986). Serotonin function in panic disorders. The effect of intravenous tryptophan in healthy subjects and patients with panic disorder before and during alprazolam treatment. Arch Gen Psychiatry 43: 1059-1065.

Charney DS, Woods SW, Goodman WK, Heninger GR (1987). Serotonin function in anxiety. II. Effects of the serotonin agonist MCPP in panic disorder patients and healthy subjects. Psychopharmacologia 92: 14-24.

Coplan JD, Gorman JM, Klein DF (1992). Serotonin related functions in panic-anxiety: a critical overview. Neuropsychopharmacology 6: 189-200.

Coplan JD, Lydiard RB (1998). Brain circuits in panic disorder. Biol Psychiatry 44: 1264-1276.

Cutler NR, Keppel Hesselink JM, Sramek JJ (1994). A phase II multicenter dose-finding, efficacy and safety trial of ipsapirone in outpatients with generalized anxiety disorder. Prog Neuropsychopharmacol Biol Psychiatry 18: 447-463.

Deakin JFW (1996). 5-HT, antidepressant drugs and the psychosocial origins of depression. J Psychopharmacol 10: 31-38.

Deakin JFW, Graeff F (1991). 5-HT and mechanisms of defence. J Psychopharmacol 5: 305-315.

den Boer JA, Westenberg HG (1990a). Behavioral, neuroendocrine, and biochemical effects of 5-hydroxytryptophan administration in panic disorder. Psychiatry Res 31: 267-278.

den Boer JA, Westenberg HG (1990b). Serotonin function in panic disorder: a double blind placebo controlled study with fluvoxamine and ritanserin. Psychopharmacologia 102: 85-94.

Deckert J, Catalano M, Heils A, Di Bella D, Friess F, Politi E et al (1997). Functional promoter polymorphism of the human serotonin transporter: lack of association with panic disorder. Psychiatr Genet 7: 45-47.

Deckert J, Catalano M, Syagailo YV, Bosi M, Okladnova O, Di Bella $\mathrm{D}$ et al (1999). Excess of high activity monoamine oxidase A gene promoter alleles in female patients with panic disorder. Hum Mol Genet 8: 621-624.
Deckert J, Meyer J, Catalano M, Bosi M, Sand P, DiBella D et al (2000). Novel 5'-regulatory region polymorphisms of the 5-HT2C receptor gene: association study with panic disorder. Int J Neuropsychopharmacol 3: 321-325.

Depot M, Caille G, Mukherjee J, Katzman MA, Cadieux A, Bradwejn J (1999). Acute and chronic role of 5-HT3 neuronal system on behavioral and neuroendocrine changes induced by intravenous cholecystokinin tetrapeptide administration in humans. Neuropsychopharmacology 20: 177-187.

Dreshfield-Ahmad LJ, Thompson DC, Schaus JM, Wong DT (2000). Enhancement in extracellular serotonin levels by 5hydroxytryptophan loading after administration of WAY 100635 and fluoxetine. Life Sci 66: 2035-2041.

Drevets WC, Frank E, Price JC, Kupfer DJ, Holt D, Greer PJ et al (1999). PET imaging of serotonin 1A receptor binding in depression. Biol Psychiatry 46: 1375-1387.

Fehr C, Grintschuk N, Szegedi A, Anghelescu I, Klawe C, Singer P et al (2000a). The HTR1B $861 \mathrm{G}>\mathrm{C}$ receptor polymorphism among patients suffering from alcoholism, major depression, anxiety disorders and narcolepsy. Psychiatry Res 97: 1-10.

Fehr C, Schleicher A, Szegedi A, Anghelescu I, Klawe C, Hiemke C et al (2001). Serotonergic polymorphisms in patients suffering from alcoholism, anxiety disorders and narcolepsy. Prog Neuropsychopharmacol Biol Psychiatry 25: 965-982.

Fehr C, Szegedi A, Anghelescu I, Klawe C, Hiemke C, Dahmen N (2000b). Sex differences in allelic frequencies of the 5-HT2C Cys23Ser polymorphism in psychiatric patients and healthy volunteers: findings from an association study. Psychiatr Genet 10: $59-65$.

Fickbohm DJ, Katz PS (2000). Paradoxical actions of the serotonin precursor 5-hydroxytryptophan on the activity of identified serotonergic neurons in a simple motor circuit. J Neurosci 20: $1622-1634$.

Frazer A, Hensler JG (1990). 5-HT1A receptors and 5-HT1Amediated responses: effect of treatments that modify serotonergic neurotransmission. Ann N Y Acad Sci 600: 460-474.

Germine M, Goddard AW, Sholomskas DE, Woods SW, Charney DS, Heninger GR (1994). Response to meta-chlorophenylpiperazine in panic disorder patients and healthy subjects: influence of reduction in intravenous dosage. Psychiatry Res 54: 115-133.

Gingrich J, Goldman D, Mann JJ, Hariri A (2004). Novel serotonin transporter gene promoter variants and psychiatric illness. Neuropsychopharmacology 29(Suppl 1): 45-46.

Goddard AW, Charney DS (1997). Toward an integrated neurobiology of panic disorder. J Clin Psychiatry 58: 4-11.

Goddard AW, Sholomskas DE, Walton KE, Augeri FM, Charney DS, Heninger GR et al (1994). Effects of tryptophan depletion in panic disorder. Biol Psychiatry 36: 775-777.

Gorman JM, Kent JM, Sullivan GM, Coplan JD (2000). Neuroanatomical hypothesis of panic disorder, revised. Am J Psychiatry 157: 493-505.

Gottesman II, Gould TD (2003). The endophenotype concept in psychiatry: etymology and strategic intentions. Am J Psychiatry 160: 636-645.

Graeff FG (1997). Serotonergic systems. Psychiatr Clin North Am 20: 723-739.

Gross C, Zhuang X, Stark K, Ramboz S, Oosting R, Kirby L et al (2002). Serotonin1A receptor acts during development to establish normal anxiety-like behaviour in the adult. Nature 416: 396-400.

Grove G, Coplan JD, Hollander E (1997). The neuroanatomy of 5-HT dysregulation and panic disorder. J Neuropsychiatry Clin Neurosci 9: 198-207.

Hamilton SP, Heiman GA, Haghighi F, Mick S, Klein DF, Hodge SE et al (1999). Lack of genetic linkage or association between a functional serotonin transporter polymorphism and panic disorder. Psychiatr Genet 9: 1-6. 
Hamilton SP, Slager SL, Heiman GA, Haghighi F, Klein DF, Hodge $\mathrm{SE}$ et al (2000). No genetic linkage or association between a functional promoter polymorphism in the monoamine oxidaseA gene and panic disorder. Mol Psychiatry 5: 465-466.

Han L, Nielsen DA, Rosenthal NE, Jefferson K, Kaye W, Murphy D et al (1999). No coding variant of the tryptophan hydroxylase gene detected in seasonal affective disorder, obsessive-compulsive disorder, anorexia nervosa, and alcoholism. Biol Psychiatry 45: 615-619.

Hariri AR, Mattay VS, Tessitore A, Kolachana B, Fera F, Goldman $D$ et al (2002). Serotonin transporter genetic variation and the response of the human amygdala. Science 297: 400-403.

Hensler JG, Kovachich GB, Frazer A (1991). A quantitative autoradiographic study of serotonin1A receptor regulation. Effect of 5,7-dihydroxytryptamine and antidepressant treatments. Neuropsychopharmacology 4: 131-144.

Hollander E, Liebowitz MR, DeCaria C, Klein DF (1990). Fenfluramine, cortisol, and anxiety. Psychiatry Res 31: 211-213.

Huang YY, Battistuzzi C, Oquendo MA, Harkavy-Friedman J, Greenhill L, Zalsman G et al (2004). Human 5-HT1A receptor C(-1019)G polymorphism and psychopathology. Int J Neuropsychopharmacol 7: 441-451.

Inada Y, Yoneda H, Koh J, Sakai J, Himei A, Kinoshita Y et al (2003). Positive association between panic disorder and polymorphism of the serotonin $2 \mathrm{~A}$ receptor gene. Psychiatry Res 118: $25-31$.

Ishiguro $\mathrm{H}$, Arinami T, Yamada K, Otsuka Y, Toru M, Shibuya $\mathrm{H}$ (1997). An association study between a transcriptional polymorphism in the serotonin transporter gene and panic disorder in a Japanese population. Psychiatry Clin Neurosci 51: 333-335.

Iversen SD (1984). 5-HT and anxiety. Neuropharmacology 23: $1553-1560$

Jacobs BL, Azmitia EC (1992). Structure and function of the brain serotonin system. Physiol Rev 72: 165-229.

Kahn RS, Asnis GM, Wetzler S, van Praag HM (1988a). Neuroendocrine evidence for serotonin receptor hypersensitivity in panic disorder. Psychopharmacologia 96: 360-364.

Kahn RS, Westenberg HG (1985). L-5-hydroxytryptophan in the treatment of anxiety disorders. J Affect Disord 8: 197-200.

Kahn RS, Westenberg HG, Verhoeven WM, Gispen-de Wied CC, Kamerbeek WD (1987). Effect of a serotonin precursor and uptake inhibitor in anxiety disorders; a double-blind comparison of 5-hydroxytryptophan, clomipramine and placebo. Int Clin Psychopharmacol 2: 33-45.

Kahn R, Wetzler S, Asnis GM, Kling MA, Suckow RF, van Praag HM (1991). Pituitary hormone responses to meta-chlorophenylpiperazine in panic disorder and healthy control subjects. Psychiatry Res 37: 25-34.

Kahn R, Wetzler S, van Praag HM, Asnis GM, Strauman T (1988b). Behavioral indications for serotonin receptor hypersensitivity in panic disorder. Psychiatry Res 25: 101-104.

Kent JM, Coplan JD, Gorman JM (1998). Clinical utility of the selective serotonin reuptake inhibitors in the spectrum of anxiety. Biol Psychiatry 44: 812-824.

Kent JM, Coplan JD, Martinez J, Karmally W, Papp LA, Gorman JM (1996). Ventilatory effects of tryptophan depletion in panic disorder: a preliminary report. Psychiatry Res 64: 83-90.

Klaassen T, Klumperbeek J, Deutz NE, van Praag HM, Griez E (1998). Effects of tryptophan depletion on anxiety and on panic provoked by carbon dioxide challenge. Psychiatry Res 77: 167-174.

Klein E, Zohar J, Geraci MF, Murphy DL, Uhde TW (1991). Anxiogenic effects of $\mathrm{m}-\mathrm{CPP}$ in patients with panic disorder: comparison to caffeine's anxiogenic effects. Biol Psychiatry 30: 973-984.

Koszycki D, Zacharko RM, Le Melledo JM, Young SN, Bradwejn J (1996). Effect of acute tryptophan depletion on behavioral, cardiovascular, and hormonal sensitivity to cholecystokinin- tetrapeptide challenge in healthy volunteers. Biol Psychiatry 40: 648-655.

Lemonde S, Turecki G, Bakish D, Du L, Hrdina PD, Bown CD et al (2003). Impaired repression at a 5-hydroxytryptamine $1 \mathrm{~A}$ receptor gene polymorphism associated with major depression and suicide. J Neurosci 23: 8788-8799.

Lerer B, Macciardi F, Segman RH, Adolfsson R, Blackwood D, Blairy S et al (2001). Variability of 5-HT2C receptor cys23ser polymorphism among European populations and vulnerability to affective disorder. Mol Psychiatry 6: 579-585.

Lesch KP, Bengel D, Heils A, Sabol SZ, Greenberg BD, Petri S et al (1996). Association of anxiety-related traits with a polymorphism in the serotonin transporter gene regulatory region. Science 274: 1527-1531.

Lesch KP, Gutknecht L (2004). Focus on the 5-HT1A receptor: emerging role of a gene regulatory variant in psychopathology and pharmacogenetics. Int J Neuropsychopharmacol 7: 381-385.

Lucki I (1998). The spectrum of behaviors influenced by serotonin. Biol Psychiatry 44: 151-162.

Marek GJ, McDougle CJ, Price LH, Seiden LS (1992). A comparison of trazodone and fluoxetine: implications for a serotonergic mechanism of antidepressant action. Psychopharmacologia 109: 2-11.

Maron E, Kuikka JT, Shlik J, Vasar V, Vanninen E, Tiihonen J (2004a). Reduced brain serotonin transporter binding in patients with panic disorder. Psychiatry Res 132: 173-181.

Maron E, Lang A, Tasa G, Liivlaid L, Tõru I, Must A et al (2005a). Associations between serotonin-related gene polymorphisms and panic disorder. Int J Neuropsychopharmacol 8: 261-266.

Maron E, Nikopensius T, Kõks S, Altmäe S, Heinaste E, Vabrit K et al (2005b). Association study of 90 candidate genetic polymorphisms in panic disorder. Psychiatr Genet 15: 17-24.

Maron E, Tasa G, Tõru I, Lang A, Vasar V, Shlik J (2004b). Association between serotonin-related genetic polymorphisms and CCK-4-induced panic attacks with or without 5-hydroxytryptophan pretreatment in healthy volunteers. World J Biol Psychiatry 5: 149-154.

Maron E, Tõru I, Vasar V, Shlik J (2004c). The effect of 5hydroxytryptophan on cholecystokinin-4-induced panic attacks in healthy volunteers. J Psychopharmacol 18: 194-199.

Matsushita S, Muramatsu T, Kimura M, Shirakawa O, Mita T, Nakai $\mathrm{T}$ et al (1997). Serotonin transporter gene regulatory region polymorphism and panic disorder. Mol Psychiatry 2: 390-392.

McCann UD, Morgan CM, Geraci M, Slate SO, Murphy DL, Post RM (1997). Effects of the 5-HT3 antagonist, ondansetron, on the behavioral and physiological effects of pentagastrin in patients with panic disorder and social phobia. Neuropsychopharmacology 17: 360-369.

Meltzer HY, Maes M (1994). Effect of pindolol on the L-5-HTPinduced increase in plasma prolactin and cortisol concentrations in man. Psychopharmacologia 114: 635-643.

Meltzer MD, Bastani MD, Jayathilake MS, Maes MD (1997). Fluoxetine, but not tricyclic antidepressants, potentiates the 5-hydroxytryptophan-mediated increase in plasma cortisol and prolactin secretion in subjects with major depression or with obsessive compulsive disorder. Neuropsychopharmacology 17: 1-11.

Miller HE, Deakin JF, Anderson IM (2000). Effect of acute tryptophan depletion on $\mathrm{CO}_{2}$-induced anxiety in patients with panic disorder and normal volunteers. $\mathrm{Br} J$ Psychiatry 176: 182-188.

Mortimore C, Anderson IM (2000). d-Fenfluramine in panic disorder: a dual role for 5-hydroxytryptamine. Psychopharmacologia 149: 251-258.

Nash JR, Sargen PA, Rabiner EA, Hood SD, Argyropoulos SV, Grasby RM et al (2004). Altered 5HT1A binding in panic disorder demonstrated by positron emission tomography. Eur Neuropsychopharmacol 14(Suppl 3): 322-323. 
Neumeister A, Bain E, Nugent AC, Carson RE, Bonne O, Luckenbaugh DA et al (2004). Reduced serotonin type $1 \mathrm{~A}$ receptor binding in panic disorder. J Neurosci 24: 589-591.

Noyes R, Crowe RR, Harris EL, Hamra BJ, McChesney CM, Chaudhry DR (1986). Relationship between panic disorder and agoraphobia. A family study. Arch Gen Psychiatry 43: 227-232.

Nutt DJ (1998). Antidepressants in panic disorder: clinical and preclinical mechanisms. J Clin Psychiatry 59: 24-28.

Nutt DJ, Forshall S, Bell C, Rich A, Sandford J, Nash J et al (1999). Mechanisms of action of selective serotonin reuptake inhibitors in the treatment of psychiatric disorders. Eur Neuropsychopharmacol 9(Suppl 3): 81-86.

Perna G, Bella D, Favaron E, Cucchi M, Liperi L, Bellodi L (2004). Lack of relationship between $\mathrm{CO}(2)$ reactivity and serotonin transporter gene regulatory region polymorphism in panic disorder. Am J Med Genet 129: 41-43.

Perna G, Bertani A, Gabriele A, Politi E, Bellodi L (1997). Modification of $35 \%$ carbon dioxide hypersensitivity across one week of treatment with clomipramine and fluvoxamine: a double-blind, randomized, placebo-controlled study. J Clin Psychopharmacol 17: 173-178.

Perna G, Favaron E, Di Bella D, Bussi R, Bellodi L (2005). Antipanic efficacy of paroxetine and polymorphism within the promoter of the serotonin transporter gene. Neuropsychopharmacology [Epub ahead of print].

Phillips RG, LeDoux JE (1992). Differential contribution of amygdala and hippocampus to cued and contextual fear conditioning. Behav Neurosci 106: 274-285.

Polesskaya OO, Sokolov BP (2002). Differential expression of the ' $\mathrm{C}$ ' and ' $\mathrm{T}$ ' alleles of the 5-HT2A receptor gene in the temporal cortex of normal individuals and schizophrenics. J Neurosci Res 67: $812-822$.

Pranzatelli MR, Durkin MM, Barkai AI (1994). Quantitative autoradiography of 5-hydroxytryptaminelA binding sites in rats with chronic neonatal 5,7-dihydroxytryptamine lesions. Brain Res Dev Brain Res 80: 1-6.

Rothe C, Gutknecht L, Freitag C, Tauber R, Mossner R, Franke P et al (2004a). Association of a functional 1019C $>$ G 5-HT1A receptor gene polymorphism with panic disorder with agoraphobia. Int J Neuropsychopharmacol 7: 189-192.

Rothe C, Koszycki D, Bradwejn J, King N, De Luca V, Shaikh S et al (2004b). Association study of serotonin-2A receptor gene polymorphism and panic disorder in patients from Canada and Germany. Neurosci Lett 363: 276-279.

Samochowiec J, Hajduk A, Samochowiec A, Horodnicki J, Stepien G, Grzywacz A et al (2004). Association studies of MAO-A, COMT, and 5-HTT genes polymorphisms in patients with anxiety disorders of the phobic spectrum. Psychiatry Res 128: 21-26.

Sanghera MK, Coke JA, Williams HL, McMillen BA (1990). Ipsapirone and 1-(2-pyrimidinyl)-piperazine increase rat locus coeruleus noradrenergic activity. Brain Res Bull 24: 17-22.

Schmidt NB, Storey J, Greenberg BD, Santiago HT, Li Q, Murphy DL (2000). Evaluating gene $\times$ psychological risk factor effects in the pathogenesis of anxiety: a new model approach. J Abnorm Psychol 109: 308-320.

Schruers K, Griez E (2004). The effects of tianeptine or paroxetine on $35 \% \mathrm{CO}_{2}$ provoked panic in panic disorder. J Psychopharmacol 18: 553-558.

Schruers K, Klaassen T, Pols H, Overbeek T, Deutz NE, Griez E (2000). Effects of tryptophan depletion on carbon dioxide provoked panic in panic disorder patients. Psychiatry Res 93: 179-187.

Schruers K, van Diest R, Overbeek T, Griez E (2002). Acute-5hydroxytryptophan administration inhibits carbon dioxideinduced panic in panic disorder patients. Psychiatry Res 113: 237-243.

Shlik J, Aluoja A, Vasar V, Vasar E, Podar T, Bradwejn J (1997). Effects of citalopram treatment on behavioural, cardiovascular and neuroendocrine response to cholecystokinin tetrapeptide challenge in patients with panic disorder. J Psychiatry Neurosci 22: $332-340$.

Smoller JW, Tsuang MT (1998). Panic and phobic anxiety: defining phenotypes for genetic studies. Am J Psychiatry 155: 1152-1162.

Solyom L (1994). Controlling panic attacks with fenfluramine. Am J Psychiatry 151: 621-622.

Spurlock G, Buckland P, O'Donovan M, McGuffin P (1994). Lack of effect of antidepressant drugs on the levels of mRNAs encoding serotonergic receptors, synthetic enzymes and 5HT transporter. Neuropharmacology 33: 433-440.

Swain J, Koszycki D, Shlik J, Bradwejn J (2003). Pharmacological challenge agents in anxiety. In: Nutt DJ, Ballenger JC (eds). Anxiety Disorders. Blackwell Science: UK. pp 269-295.

Tadic A, Rujescu D, Szegedi A, Giegling I, Singer P, Moller HJ et al (2003). Association of a MAOA gene variant with generalized anxiety disorder, but not with panic disorder or major depression. Am J Med Genet 117: 1-6.

Talbot PS (2004). The molecular neuroimaging of anxiety disorders. Curr Psychiatry Rep 6: 274-279.

Targum SD, Marshall LE (1989). Fenfluramine provocation of anxiety in patients with panic disorder. Psychiatry Res 28: 295-306.

Tyrer P, Shawcross C (1988). Monoamine oxidase inhibitors in anxiety disorders. J Psychiatr Res 22: 87-98.

van Megen HJ, Westenberg HG, den Boer JA, Slaap B, Scheepmakers A (1997). Effect of the selective serotonin reuptake inhibitor fluvoxamine on CCK-4 induced panic attacks. Psychopharmacologia 129: 357-364.

van Vliet IM, Slaap BR, Westenberg HG, Den Boer JA (1996). Behavioral, neuroendocrine and biochemical effects of different doses of 5-HTP in panic disorder. Eur Neuropsychopharmacol 6: $103-110$.

Verge D, Daval G, Marcinkiewicz M, Patey A, Mestikawy S, Gozlan $\mathrm{H}$ et al (1986). Quantitative autoradiography of multiple 5-HT1 receptor subtypes in the brain of control or 5,7-dihydroxytryptamine-treated rats. J Neurosci 6: 3474-3482.

Welner SA, De Montigny C, Desroches J, Desjardins P, SuranyiCadotte BE (1989). Autoradiographic quantification of serotonin1A receptors in rat brain following antidepressant drug treatment. Synapse 4: 347-352.

Wetzler S, Asnis GM, DeLecuona JM, Kalus O (1996). Serotonin function in panic disorder: intravenous administration of metachlorophenylpiperazine. Psychiatry Res 64: 77-82.

Wu S, Comings DE (1999). A common C-1018G polymorphism in the human 5-HT1A receptor gene. Psychiatr Genet 9: 105-106.

Young SN, Smith SE, Pihl RO, Ervin FR (1985). Tryptophan depletion causes a rapid lowering of mood in normal males. Psychopharmacologia 87: 173-177.

Zhang X, Beaulieu JM, Sotnikova TD, Gainetdinov RR, Caron MG (2004). Tryptophan hydroxylase-2 controls brain serotonin synthesis. Science 305: 217. 